\title{
Influence of the Mycorrhizal Glomus intraradices on the Development of In Vitro Raised Olive Seedlings During Acclimation Phase.
}

\author{
A. Troncoso, J. Liñán, C.L. Carretero, J.L. Garcia, J. Troncoso, M. García and M. Cantos \\ Instituto de Recursos Naturales y Agrobiología (CSIC). Av Reina Mercedes 10, 41012 \\ Sevilla, Spain.
}

Keywords: olive seedlings, vesicular-arbuscular mycorrhizal, Glomus intraradices, acclimatation phase.

\begin{abstract}
For olive genetic improvement work it is very important to obtain a high rate of seed germination and a shortening of the juvenile period of the plants raised. By in vitro embryo culture, a $100 \%$ of germination is attained in a few days and the supply of adequate nutritive solutions and photoperiod speeds up seedling development during hardening, thus shortening juvenility. Mycorrhizal is another resource to improve plant development. This work attempts to know the effect of the vesicular-arbuscular mycorrhizal Glomus intraradices on the survival and development of olive seedlings obtained by in vitro embryo germination, during greenhouse hardening phase.

Olive seedlings obtained by in vitro embryo germination were transplanted to pots with sterile sandy soil. Half of the pots were inoculated with $5 \mathrm{~g}$ of Glomus intraradices. Afterwards, the pots were transferred to a greenhouse and watered at field capacity. After 180 days in this conditions, the number of dead plants, stem and shoot length of the surviving plants, and leaves, stems, shoots, roots and whole plant fresh and dry weight were recorded. Also, the nutritive status of the above indicated organs was analysed. $\mathrm{N}$ was determined by Kjeldahl digestion and mineral nutrients $(\mathrm{P}, \mathrm{K}, \mathrm{Ca}, \mathrm{Mg}, \mathrm{Fe}, \mathrm{Mn}, \mathrm{Cu}$, $\mathrm{Zn}$ ) by ICP-OES. Soil texture was determined according to the method of Gee and Bauder (1986) and chemical fertility according to Page et al. (1982).

The treatment with mycorrhizal fungus Glomus intraradices significatively increased (from 71 to $88 \%$ ) the number of surviving plants after ex vitro transfer. The effect of the symbiosis plant-fungus was even more spectacular on the development of the surviving plants, three-folding fresh weight, dry weight and plant size (from 6 to $18 \mathrm{~g}, 2.5$ to $7.6 \mathrm{~g}$ and 31 to $91 \mathrm{~cm}$, respectively) after 180 days of culture. The better growth of the treated plants coincided with a higher nutrient acquisition, particularly $\mathrm{P}$, in a low chemical fertility medium, as was the substrate used.
\end{abstract}

\section{INTRODUCTION}

For the olive breeding works it is very important to reach a high proportion of seed germination and a shortening of the juvenile improductive phase. By in vitro culture of isolated mature olive embryos very high germination percentages have been obtained (Troncoso et al., 1991; Voyiatzis and Pritsa, 1994; Voyiatzis, 1995) in few days, even reaching 100\% (Acebedo et al., 1997) and by using appropriate nitrogen forms and concentrations (García et al., 1994; Sarmiento et al., 1994) and sugar (García et al., 2002) a high in vitro growth of the seedlings was obtained. The use of a suitable substratum (Rugini, 1984), nutritive solutions (García et al., 1999) and photoperiod (Alvarado, 1994) during the hardening phase also increases the plant development. With the plants in the field, pruning and cultivation conditions also influence their growth speed (Lavee, 1990; Lavee et al., 1996; García-Ortiz et al., 2001; Navarro and Parra, 2001). Due to the 
existence of a relationship between plant development and length of the juvenile phase (Natividade, 1957; Rugini, 1986; Bellini, 1993) the increase of growth indicated in the above works leads to a shortening of olive plant juvenile period (Acebedo et al., 1997; Liñán et al., 1999). Nevertheless, it would be necessary to shorten even more the olive juvenility by further increasing of the plant growth speed.

Arbuscular mycorrhizal (AM) is a very effective method to increase plant survival and development during hardening (Hooker et al., 1994; Azcón-Aguilar et al., 1997) and consequently it would help to shorten plant juvenility. Also, as olive tree normally grow in bad quality soils, the results obtained with mycorrhizal young olive plants growing in poor substratum could be of interest to be applied in field situations. This work aims to know the effect of the mycorrhizal olive plant-Glomus intraradices fungus on the survival, growth and mineral composition during the hardening of olive seedlings (cv Manzanillo) obtained in vitro by mature embryo germination.

\section{MATERIAL AND METHODS}

Manzanillo olive seedlings obtained from in vitro embryo germination were transplanted after 60 days of in vitro culture to outside conditions according to Cantos et al. (1993). After 20 days of a first hardening period in a culture chamber, 16 plants were newly transferred to pots with $2 \mathrm{~kg}$ of sterile sandy soil (Table 1) and other 16 plants to similar pots with the same quantity of the same soil but previously mycorrhized by Glomus intraradices fungus (isolate 11AG8903). Micorrhizal inoculum was provided by R. Azcón (E.E. "Zaidin", CSIC, Granada, Spain) and consisted in a mixed rhizosphere samples containing spores, hyphae and mycorrhizal root fragments. Twenty grams of inoculum were added to each pot. The potted plants were placed in a greenhouse where only received tap water irrigation, maintaining the substratum at field capacity.

The number of dead plants, and stem, shoots and total growth of each plant were recorded at 0 (initial), 30 and 180 (final) days of greenhouse cultivation. At the end of the experiment, presence of fungus in the plant roots was checked by treating the roots with hot $10 \% \mathrm{KOH}$, stained with $0.05 \%$ Trypan blue in lactic acid, de-stained with $50 \%$ glycerol, mounted on slides, and observed directly under microscope (Phillips and Hayman, 1970). Nutritional status of the plants (roots, stem-shoots and leaves) were also analised. $\mathrm{N}$ was determined by Kjeldahl digestion and mineral nutrients $(\mathrm{P}, \mathrm{K}, \mathrm{Ca}, \mathrm{Mg}$, $\mathrm{Fe}, \mathrm{Mn}, \mathrm{Cu}, \mathrm{Zn}$ ) by wet oxidation with concentrated $\mathrm{HNO}_{3}$ under pressure using a Milestone Ethos microwave digestion system. Analyses of mineral nutrients in the extracts was performed by ICP-OES.

Particle size distribution in soil samples $(2 \mathrm{~mm})$ was determined by the hydrometer method (Gee and Bauder, 1986) and the soil chemical properties (Table 1) were determined according to Page et al. (1982).

Stem and shoot length was measured with a ruler and the total plant size was considered the sum of the length of the stem and each shoot. Fresh and dry weights were determined and hydration calculated from the formula:

$$
H=\left(\frac{f w-d w}{f w}\right) \times 100
$$




\section{RESULTS AND DISCUSSION}

The soil used as substratum (Table 1) is a sandy, neutral $\mathrm{pH}$ soil, very poor in calcium carbonate. It has very low levels of organic matter $(\mathrm{OM}), \mathrm{N}, \mathrm{Ca}$ and $\mathrm{Mg}$ and also low P, K, and Fe. Then, the soil can be considered of low fertility.

Figure 1 shows the presence of Glomus intraradices hyphae in the roots of the mycorrhizal olive plants, indicating that symbiosis had occurred.

As a consequence of the transplanting crisis, 7 plants of the control group and only 3 of the treated died. This could be a first beneficial effect of the plant-fungus symbiosis.

There were no significant differences in the growth, both apical (stem) and lateral (shoots) and the total plant between mycorrhizal and non mycorrhizal plants during the first 30 days of cultivation (Table 2). But at the end of the experiment (180 days) the stem of the mycorrhizal plants had reached double length of that of control plants and also the number of new lateral shoots of the treated plants was significantly higher than control. Due to this, the average growth of the lateral shoots of inoculated plants was higher than the control but not enough to be significant. The greater apical and total lateral (average per number of shoot) growth provoked that mycorrhizal plants reached after 180 days of cultivation a length 3 times higher than the control plants (Table 2).

Due to a greater size, mycorrhizal plants had higher fresh and dry weights for every organ considered and as total plant (Table 3). Mycorrhizal also provoked a higher hydration level in root and leaf indicating more efficient water absorption.

Nutrient levels were also affected by mycorrhizal (Tables 4 and 5). When the nutrient content was considered as a percentage or ppm, only the values for $\mathrm{P}$ and $\mathrm{Fe}$ of the mycorrhizal plants were clearly higher than control (Table 4). But if the total quantity per plant of each element is compared, the mycorrhizal plants, because of its greater size, show higher levels than control for all the nutrients considered, particularly $\mathrm{P}$ and $\mathrm{Fe}$.

Due to the low fertility of the substratum (Table 1) and the irrigation with only tap water, the control plants developed poorly (Tables 2 and 3), less than similar olive plants irrigated with nutritive solution (García et al., 1999). Despite of the bad nutritive conditions, the olive plants inoculated with Glomus intraradices improved survival after in vitro-ex vitro transplanting and increased development (Tables 2 and 3). The positive influence of mycorrhiza on plant development was reported by Abbott and Robson (1984) for plants under poor fertility conditions. The positive effect of mycorrhizal was related to better root and leaf hydration (Table 3 ) and higher nutrient absorption, mainly $\mathrm{P}$ and $\mathrm{Fe}$ (Tables 4 and 5). Some authors (Rosendahl and Rosendahl, 1991; Subramanian et al., 1997; Abdel-Fattah and Shabana, 2002) reported the positive influence of mycorrhizal on plant water content and others (Timmer and Leyder, 1978; Tinker, 1980; Allen and Cunningham, 1983; Pons et al., 1983; Barea, 1991; Tobar et al., 1994a;b; Azcón et al., 1996) related mycorrhizal with a better nutritional status. Clark and Zeto (2000) related this plant-fungus behaviour with a greater colonisation of soil volume, absorption and excretion of some chemical compounds.

Thus, mycorrhizal improve survival and development of olive seedlings in poor soil and fertility conditions which could be of interest for both shortening juvenile phase and plant cultivation of olive in bad quality soils.

\section{References}

Abbott L.K. and Robson A.D. 1984. The effect of mycorrhizas on plant growth. In: VA Mycorrhiza, CLl Powell \& DJ Bagyaraj (eds), CRC Press, Boca Raton, Florida, pp. 113-130. 
Abdel-Fattah GM and Shabana YM. 2002. Efficacy of the arbuscular mycorrhizal fungus Glomus clarum in protection of cowpea plants against root rot pathogen Rhizoctonia solani. Zeitschrift Fur Pflanzenkrankheiten Und Pflanzenschutz-Journal Of Plant Diseases And Protection, 109(2):207-215.

Acebedo M.M., Lavee S., Liñán J. and Troncoso A. 1997. In vitro germination of embryos for speeding up seedling development in olive breeding programmes. Sci. Hort., 69: 207- 215.

Allen E.B. and Cunningham G.L. 1983. Effects of vesicular-arbuscular mycorrhizae on Distichlis spicata under three salinity levels. New Phytol., 93: 227-236.

Alvarado J. 1994. Métodos para la germinación y crecimiento forzado de plántulas en olivo. Trabajo Profesional Fin de Carrera, ETSIAM, Universidad de Córdoba.

Azcón R., Gómez M. and Tobar R. M. 1996. Physiological and nutritional responses by Lactuca sativa L. to nitrogen sources and mycorrhizal fungi under drought conditions. Biol. Fertil. Soils, 22: 156-161.

Azcón-Aguilar C., Troncoso A., Cantos M. and Barea, J.M. 1997. Beneficial effect of arbuscular mycorrhizas on acclimatization of micropropagated cassava plantlets. Sci. Hort., 72(1):63-71.

Barea J.M. 1991. Vesicular-arbuscular mycorrhizae as modifiers of soil fertility. Adv. Soil Sci., 15:1-39.

Bellini, E., 1993. Variabilidad genética y heredabilidad de algunos caracteres en las plantas de semillas de olivo obtenidas por cruzamiento. Olivae, 49: 21-34.

Cantos M., Liñán J., Pérez-Camacho F. and Troncoso A. 1993. Obtención de plantas selectas de vid, variedad Zalema, libres de virosis de entrenudo corto. Actas de Horticultura, 1: 705-709.

Clark R.B. and Zeto S.K. 2000. Mineral acquisition by arbuscular mycorrhizal plants. J. Plant Nutr., 23(7): 867-902.

García J.L., Sarmiento R., Troncoso A. and Mazuelos C. 1994. Effect of the nitrogen source and concentration on $\mathrm{N}$ fractions in olive seedlings. Acta Hortic., 356: 193196.

García J.L., Liñán J. and Troncoso A. 1999. Effect of different $\mathrm{N}$ forms and concentrations on olive seedlings growth. Acta Hortic., 474:323-328.

García J.L., Troncoso J., Sarmiento R. and Troncoso A. 2002. Influence of carbon source and concentration on the in vitro development of olive zygotic embryos and explants raised from them. Plant Cell, Tiss. Org. Cult., 69: 95-100.

García-Ortiz A., Fernández A., Pastor M. and Humanes J. 2001. In: El cultivo del olivo. D. Barranco, Fernández-Escobar \& L. Rallo (eds.), Junta de Andalucía, Consejería de Agricultura y Pesca y Ediciones Mundi-Prensa, pp. 335-370.

Gee G.W. and Bauder J.W. 1986. Particle-size Analysis. In: Methods of Soil Analysis. Part 1. Physical and Mineralogical Methods, A. Klute (ed.), Cap. 15, pp. 383-411. $2^{\mathrm{a}}$ Ed. Monografia $n^{\circ} 9$ de la serie Agronomy. American Society of Agronomy. Madison. Wisconsin.

Hooker J.E., Gianinazzi S., Vestberg M., Barea J.M. and Atkinson D. 1994. The application of arbuscular mycorrhizal fungi to micropropagation systems: an opportunity to reduce inputs. Agric. Sci. Fin., 3:227-232.

Lavee S. 1990. Aims, methods, and advances in breeding of new olive (Olea europaea L.) cultivars. Acta Hortic., 286:23-36.

Lavee S., Avidan N., Haskal A. and Ogrodovich A. 1996. Juvenility period reduction in the olive seedlings - A tool for enhancement of breeding. Olivae, 60:33-41. 
Liñán J., Troncoso A. and Rapoport H.F. 1999. Olive embryo development stage and the possibility of obtaining viable seedlings. Acta Hortic., 474:75-78.

Natividade J.V., 1957. Juvenilidade na Olea europaea L. Agron. Lusit., 19: 145-159.

Navarro C. and Parra M.A. 2001. In: El cultivo del olivo. D. Barranco, FernándezEscobar \& L. Rallo (Eds.), Junta de Andalucía. Consejería de Agricultura y Pesca y Ediciones Mundi-Prensa, pp. 173-216.

Page A.L., Miller R.H., Keeney D.R. (ed.). 1982. Methods of Soil Analysis. Part 2. Chemical and Microbiological Properties. $2^{\mathrm{a}}$ ed. Monografia $\mathrm{n}^{\circ} 9$ de la serie Agronomy. American Society of Agronomy. Madison. Wisconsin.

Phillips J.M. and Hayman D.S. 1970. Improved procedure for clearing roots and staining parasitic and vesicular-arbuscular mycorrhizal fungi for rapid assessment of infection. Transactions of the British Mycological Society, 55, 158.

Pons F., Gianinazzi-Pearson V., Gianinazzi S. and Navatel J.C. 1983. Studies of VA mycorrhizal synthesis of axenically propagated wild cherry (Prunus avium L.) plants. Plant Soil, 71: 217-221.

Rosendahl C.N. and Rosendahl S. 1991. Influence of vesicular-arbuscular mycorrhizal fungi (Glomus pp) on the response of cucumber (Cucumis sativus L.) Environ. Exp. Bot., 31(3):313-318.

Rugini E. 1984. In vitro propagation of some olive (Olea europea sativa L.) cultivars with different root-ability, and medium developement using analytical data from developing shoots and embryos. Sci. Hort., 24: 123-134.

Rugini E. 1986. Olive (Olea europea L.). In: YPS Bajaj (ed.), Biotecnology in Agriculture and Forestry. I. Trees. Springer-Verlag, Berlín, pp 515.

Sarmiento R., Garcia J.L., Mazuelos C., Liñan J. and Troncoso A. 1994. Effect of the form and concentration of $\mathrm{N}$ on the growth and mineral composition of young olive seedlings. Acta Hortic., 356: 156-161.

Subramanian KS, Charest C, Dwyer LM, Hamilton RI. 1997. Effects of arbuscular mycorrhizae on leaf water potential, sugar content, and P content during drought and recovery of maize. Can. J. Bot., 75(9): 1582-1591.

Timmer L.W. and Leyden R.F. 1978. Stunting of citrus seedlings in fumigated soils in Texas and its correction by phosphorus fertilization and inoculation with mycorrhizal fungi. J. Am. Soc. Hort. Sci., 103: 533-537.

Tinker P.B. 1980. Role of rhizosphere micro-organisms in phosphorus uptake by plants. In: SE Kwasahneh, EC Sample \& EJ Kamprath (Eds.), The Role of Phosphorus in Agriculture. American Society of Agronomy. Madison. pp. 617-654.

Tobar R.M., Azcón R. and Barea J.M. 1994a. Improved nitrogen uptake and transport from $15 \mathrm{~N}$-labelled nitrate by external hyphae of arbuscular mycorrhiza under waterstressed conditions. New Phytol., 126: 119-122.

Tobar R.M., Azcón R. and Barea J.M. 1994b. The improvement of plant N acquisition from an ammonium-treated, drought-stressed soil by the fungal symbiont in arbuscular mycorrhizae. Mycorrhiza, 4: 105-108.

Troncoso A., Han N., García J.L. and Sarmiento R. 1991. Efecto de la concentracion de Nitrogeno en el desarrollo de embriones de olivo "in vitro". Ninth Consultation of the European Cooperative Research net-work on olive. Turquía. Bornova, Ishmir.

Voyiatzis D.G. 1995. Dormancy and germination of olive embryos as affected by temperature. Phisyol. Plant., 95: 444-448.

Voyiatzis D.G. and Pritsa T. 1994. The onset and disappearance of relative dormancy of olive embryos as affected by age. Acta Hortic., 356, 148-151. 
Table 1. Characteristics of the soil used as substratum.

\begin{tabular}{|c|c|c|c|c|c|c|c|c|c|c|c|}
\hline \multicolumn{3}{|c|}{ Texture (\%) } & \multicolumn{4}{|c|}{$\%$} & \multicolumn{5}{c|}{$\mathrm{mgkg}^{-1}$} \\
\cline { 1 - 8 } & & $\mathrm{CaCO}_{3}$ & $\mathrm{OM}$ & $\mathrm{N}$ & $\mathrm{P}$ & $\mathrm{K}$ & $\mathrm{Ca}$ & $\mathrm{Mg}$ & $\mathrm{Fe}$ \\
\hline 76 & 8 & 16 & 7 & 1 & 0.8 & 0.03 & 16 & 199 & 161 & 113 & 20 \\
\hline
\end{tabular}

Table 2. Statistical differences between average growth of the non mycorrhizal (control) and mycorrhizal olive plants. Different letters in rows indicate significance at the $\mathrm{p} \leq 0.01$ level among control and mycorrhizal plants.

\begin{tabular}{|c|l|c|l|}
\hline \multirow{2}{*}{$\begin{array}{c}\text { Days from } \\
\text { transplanting }\end{array}$} & & \multicolumn{2}{|c|}{ Treatment } \\
\cline { 2 - 4 } & & $\begin{array}{c}\text { Non mycorrhizal } \\
\text { olive plants }\end{array}$ & $\begin{array}{l}\text { Micorrhizal } \\
\text { olive plants }\end{array}$ \\
\hline \multirow{3}{*}{0} & Stem $(\mathrm{cm})$ & $6.43^{\mathrm{a}}$ & $6.56^{\mathrm{a}}$ \\
& Shoot $(\mathrm{cm})$ & $0.40^{\mathrm{a}}$ & $0.43^{\mathrm{a}}$ \\
& Shoot $\left(\mathrm{n}^{\mathrm{o}}\right)$ & $0.25^{\mathrm{a}}$ & $0.31^{\mathrm{a}}$ \\
& Total $(\mathrm{cm})$ & $6.59^{\mathrm{a}}$ & $7.21^{\mathrm{a}}$ \\
\hline \multirow{4}{*}{30} & Stem $(\mathrm{cm})$ & $7.55^{\mathrm{a}}$ & $7.34^{\mathrm{a}}$ \\
& Shoot $(\mathrm{cm})$ & $1.57^{\mathrm{a}}$ & $2.31^{\mathrm{a}}$ \\
& Shoot $\left(\mathrm{n}^{\mathrm{a}}\right)$ & $1.14^{\mathrm{a}}$ & $1.27^{\mathrm{a}}$ \\
& Total $(\mathrm{cm})$ & $8.88^{\mathrm{a}}$ & $9.61^{\mathrm{a}}$ \\
\hline \multirow{4}{*}{180} & Stem $(\mathrm{cm})$ & $21.22^{\mathrm{a}}$ & $44.76^{\mathrm{b}}$ \\
& Shoot $(\mathrm{cm})$ & $6.06^{\mathrm{a}}$ & $8.42^{\mathrm{a}}$ \\
& Shoot $\left(\mathrm{n}^{\mathrm{a}}\right)$ & $1.62^{\mathrm{a}}$ & $6.00^{\mathrm{b}}$ \\
& Total $(\mathrm{cm})$ & $31.33^{\mathrm{a}}$ & $91.03^{\mathrm{b}}$ \\
\hline
\end{tabular}

Table 3. Fresh and dry weights, and hydration of the mycorrhizal and non mycorrhizal olive plants after 180 days of cultivation. Different letters in rows indicate significance at the $p \leq 0.01$ level among control and mycorrhizal plants.

\begin{tabular}{|c|l|c|c|}
\hline \multirow{2}{*}{} & & \multicolumn{2}{|c|}{ Treatment } \\
\cline { 3 - 4 } & & $\begin{array}{c}\text { Non mycorrhizal } \\
\text { olive plants }\end{array}$ & $\begin{array}{c}\text { Micorrhizal } \\
\text { olive plants }\end{array}$ \\
\hline \multirow{3}{*}{ Root } & f.w. (g) & $3.0^{\mathrm{a}}$ & $6.9^{\mathrm{b}}$ \\
& d.w. (g) & $1.0^{\mathrm{a}}$ & $1.8^{\mathrm{ab}}$ \\
& H (\%) & $66.6^{\mathrm{a}}$ & $73.9^{\mathrm{b}}$ \\
\hline \multirow{2}{*}{ Stem and } & f.w. (g) & $1.5^{\mathrm{a}}$ & $5.7^{\mathrm{b}}$ \\
shoots & d.w. (g) & $0.8^{\mathrm{a}}$ & $3.0^{\mathrm{b}}$ \\
& H (\%) & $46.6^{\mathrm{a}}$ & $47.3^{\mathrm{a}}$ \\
\hline \multirow{3}{*}{ Leaf } & f.w. (g) & $1.5^{\mathrm{a}}$ & $5.5^{\mathrm{b}}$ \\
& d.w. (g) & $0.8^{\mathrm{a}}$ & $2.4^{\mathrm{b}}$ \\
& H (\%) & $46.6^{\mathrm{a}}$ & $56.4^{\mathrm{b}}$ \\
\hline \multirow{3}{*}{ Total plant } & f.w. (g) & $6.0^{\mathrm{a}}$ & $18.1^{\mathrm{b}}$ \\
& d.w. (g) & $2.6^{\mathrm{a}}$ & $7.2^{\mathrm{b}}$ \\
& H (\%) & $56.6^{\mathrm{a}}$ & $60.2^{\mathrm{ab}}$ \\
\hline
\end{tabular}


Table 4. Nutrient contents in the mycorrhizal and non mycorrhizal plants after 180 days of cultivation.

\begin{tabular}{|l|c|c|c|c|c|c|c|c|c|c|}
\hline & \multicolumn{4}{|c|}{ \% d.w. } & \multicolumn{5}{c|}{ ppm } \\
\cline { 2 - 11 } & $\mathrm{N}$ & $\mathrm{P}$ & $\mathrm{K}$ & $\mathrm{Ca}$ & $\mathrm{Mg}$ & $\mathrm{Fe}$ & $\mathrm{Mn}$ & $\mathrm{Cu}$ & $\mathrm{Zn}$ & $\mathrm{B}$ \\
\hline Non mycorrhizal & 1.66 & 0.04 & 0.77 & 0.86 & 0.15 & 568 & 66 & 16 & 11 & 17 \\
Mycorrhizal & 1.46 & 0.10 & 0.78 & 0.85 & 0.15 & 1023 & 48 & 22 & 10 & 15 \\
\hline
\end{tabular}

Table 5. Total nutrient contents in the mycorrhizal and non mycorrhizal plants after 180 days of cultivation.

\begin{tabular}{|l|c|c|c|c|c|c|c|c|c|c|}
\hline & \multicolumn{4}{|c|}{ mg per plant } & \multicolumn{6}{c|}{$\mu g$ per plant } \\
\cline { 2 - 11 } & $\mathrm{N}$ & $\mathrm{P}$ & $\mathrm{K}$ & $\mathrm{Ca}$ & $\mathrm{Mg}$ & $\mathrm{Fe}$ & $\mathrm{Mn}$ & $\mathrm{Cu}$ & $\mathrm{Zn}$ & $\mathrm{B}$ \\
\hline Non mycorrhizal & 40 & 1 & 20 & 22 & 4 & 1 & 0.2 & 0.04 & 0.03 & 0.04 \\
Mycorrhizal & 110 & 7 & 56 & 61 & 11 & 7 & 0.3 & 0.15 & 0.07 & 0.10 \\
\hline
\end{tabular}

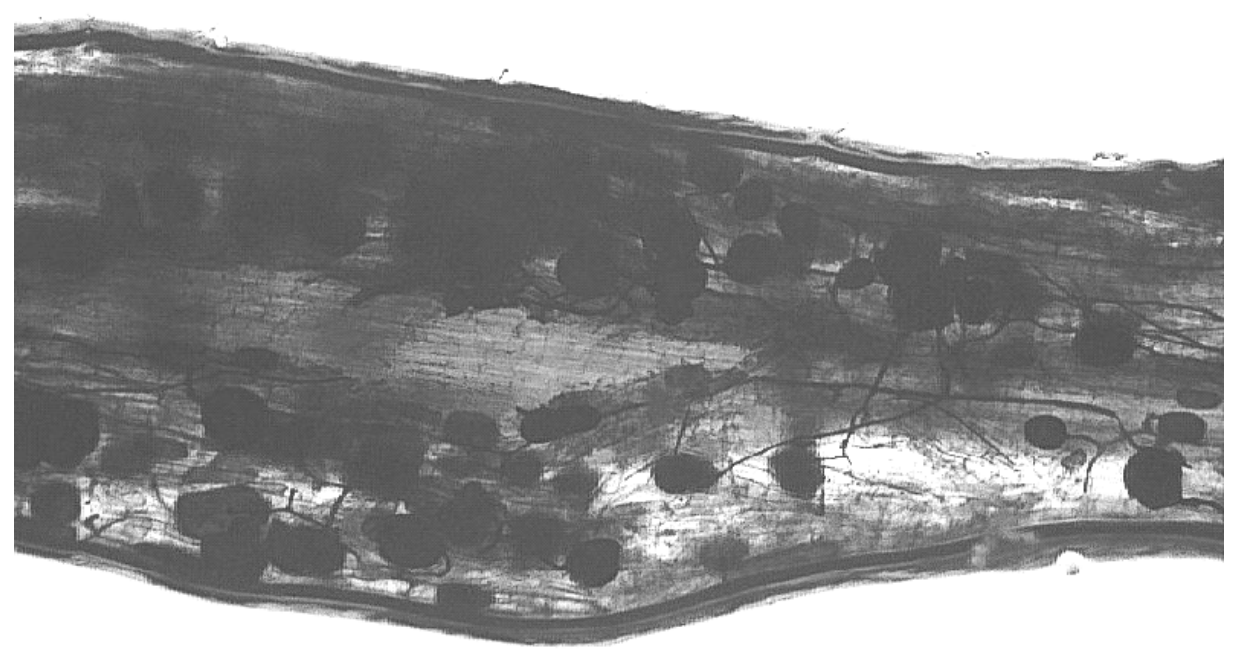

Figure 1. Root section of mycorrhizal olive plants under optical microscope after staining with Trypan blue. Numerous vesicles along with the arbuscule-hyphal network can be seen indicating that symbiosis had occurred. 